\title{
Incidents and Accidents in Plein Air Painting: One Path Towards Post-impressionism
}

\author{
Lloyd Bennett \\ Thompson Rivers University, Kamloops, Canada
}

\begin{abstract}
A method for placing oil paint in metal tubes occurred in the early 1840s, which facilitated artists taking their materials out of doors to paint nature directly. In France in the 1860s, we know of painters like Claude Monet were working on beaches and port cities to capture the effect of scenes under natural light. By 1874 the Anonymous Society of Painters, Sculptors, Engravers, etc. (Impressionists) offered their first public exhibition to much criticism. A common complaint of the new work was that it lacked finish to be considered as a completed work for sale. It is the view of this paper that outdoor, or plein air painting, developed because of the circumstances this type of work developed in the artist naturally. I focus on two areas that outdoor painting forced the artist to consider: incidents and accidents. The incidents refer to the varied weather the painter had to deal with and the accidents identify the intuitive methods the plein air painters fell practice to when confronted by difficult passages or situations in nature. These experiences would shift the focus of the Impressionists from recording nature in a naturalistic way to self-expression, which would become a key idea in early modern painting. The finish the detractors of Impressionism called for would be replaced by an appreciation for the personal in painting as exacting images of landscape became predictable and lacked the vitality of the intuitive picture that could offer something new to art.
\end{abstract}

Keywords: plein, air impressionists, painting, gestures, accidents

"Never have I been so unlucky with the weather.”

Claude Monet (Ruskin, 1973, p. 148)

\section{Introduction}

As has been stated, many times, Impressionism was the logical conclusion to 19th-century naturalism. When Claude Monet took his canvases out of doors, ${ }^{1}$ he was making the final act to record light on form before nature firsthand. His approach of using stipple marks or the color-patch of Eduard Manet, allowed for quicker painting and a systematic approach to delineating the subject. These tools enabled the Impressionists to paint faster to capture the last vestige of a tone, but something else happened in this mission to record nature: incidents and accidents. The weather might bring on disturbances to the usual plan of painting from a selected prospect or a difficult passage in the scene might cause experimentation with gestural brushwork. This allowed for another approach to painting out of doors where nature, or what Camille Corot called "the muse of the

Lloyd Bennett, Ph.D., Art Historian/Associate Professor, Thompson Rivers University.

${ }^{1}$ Monet first painted out of doors with Johann Jongkind and Eugene Boudin. "Boudin participated in the first Impressionist exhibition in 1874, and also exhibited in the annual Salon that year. He did not participate in any subsequent Impressionist exhibitions, preferring instead to stick to the Salon system.” See Beth Gersh-Nesic, thoughtco.com/eugeneboudin-quickfacts-183339 (05/07/2017). 
woods" (Shikes \& Harper, 1980, p. 35) had a hand to play in determining the outcome of the picture. This chance composition or intuitive approach to brushwork would later be developed in early modern art styles, but the first discoveries of giving up control in painting were realized by the Impressionists when they took their surfaces and oil paint tubes into nature. ${ }^{2}$

Monet's naturalism ranged from detailed observation, as in the foliage and dresses in his 1866 painting Women in the Garden to the very sketchy Impression, Sunrise from 1873. We can assume that, the subject and the circumstances of the time of the work determined the method for painting. The patchwork of leaves in the garden painting seem more fixed, over a longer period as opposed to the transient of light in the sunrise oil, this work was completed with a minimal application of gestures with thinned out oil paint. Still, it must have presented a pleasant surprise to Monet to see the results of gesture painting that likely would not have come from a more labored study of the prospect in nature. At some point, with the artist painting out of doors, Monet determined that an effective approach would be to combine structure with the spontaneous. It was a way of giving up some control for vitality that comes from the gestural approach to painting (see Figure 1).

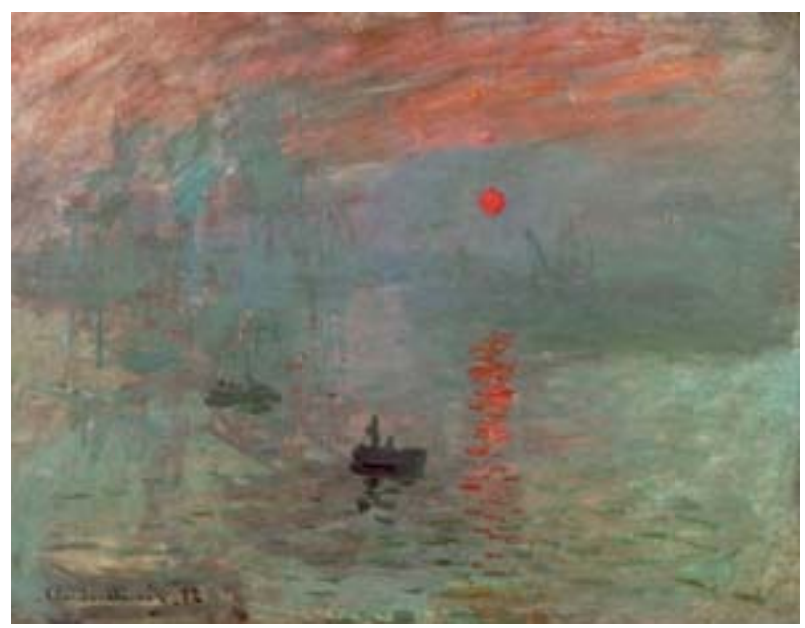

Figure 1. Claude Monet. Impression, Sunrise, 1873 (wikiart).

\section{Incidents}

We have extensive material from Monet’s biographer Daniel Wildenstein and Vincent van Gogh’s letters to his brother Theo that have become important resources for understanding the workings of the artist out of doors. In a note from 1885, Monet described an event at the Porte d'Aval where he encountered the difficulties of working near water:

I was deep in my work, completely sheltered from the wind, at the foot of the cliff, at the place we went to together; convinced the tide was going out. I wasn't worried about the little waves coming almost up to my feet. In short, I was so absorbed, I failed to see an enormous wave that flung me against the cliff and set me rolling in the backwash with all my things! My immediate thought was, I'm a goner, the water was dragging me along, but I finally got on all fours, in such a state, Lord! My boots, my woolen socks and coat were soaked; the palette, still in my hand, hit me in the face, so my beard was covered in blue, yellow etc. Once I got over the shock, it was nothing, the worst thing was I lost my picture, which was quickly broken, along with my bag, my easel etc. Impossible to fish anything out. I had all been splintered by the waves, anyhow... In short, a lucky escape. (Wildenstein, 2016, p. 265)

\footnotetext{
${ }^{2}$ Oil paint became available in tubes in 1841.
} 


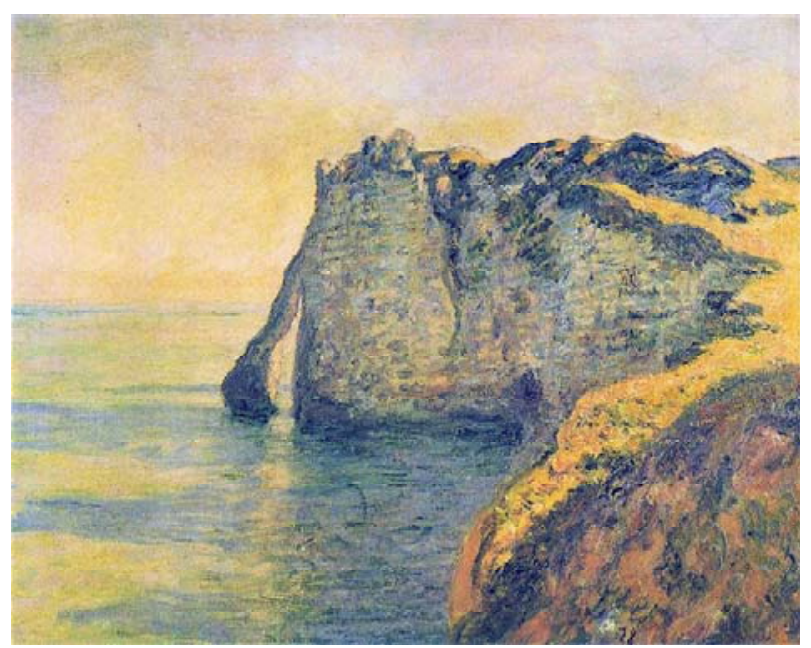

Figure 2. Claude Monet, The Cliffs at the Porte d'Aval, 1885 (wikiart).

The passage described how dangerous the waves could be, if Monet had hit his head on the cliff rock (see Figure 2) it might have been more than the painting that would have been lost. This account naturally brings excitement to the prospect of painting out of doors, making each encounter before nature a special occasion where the outcome is unknown. We should think that the subject would have been given scrutiny as each attempt carried with it consequences, not only for the picture claimed but the wellbeing of the artist. Somehow, plein air painting might be viewed as more valuable- you had to physically go and get it. Of course, the weather would determine how the painter worked in terms of the viewpoint selected (providing cover) or speed of painting as influenced by the surroundings such as fading light or approaching weather conditions.

One of the most unusual accounts of Monet painting in nature occurs when the painter tried to turn back spring. Wildenstein described a situation involving painting the oak at the Creuse Rivers in May 1889 (see Figure 3):

Monet decided to prolong the empire of winter by artifice. The oak at the confluence of the two Creuses was sacrificed to this strange ploy. On 6 May, Monet had made a large sketch of its leafy mass standing above the yellow rivers of the Creuse, but, now, thinking of the many pictures in which it featured, most of which were unfinished, he offered the owner of the land 50 francs "to have all leaves removed" and restore the trees to the winter state in which he had depicted it hitherto. The land owner gave his permission, and on 8 May, two men, leaning away from ladders which had been lowered with great difficulty into the ravine began to strip the oak of its leaves. (Wildenstein, 2016, p. 318)

Perhaps it was odd that an Impressionist should lament the arrival of spring, but because Monet worked in series (up to nineteen canvases at a time) he would not have wanted to adjust all the pictures to the new season colors. Therefore, he adjusted nature and moved back in time for his tree. ${ }^{3}$

\footnotetext{
${ }^{3}$ Monet would use his ingenuity to organize his prospect in the city, as well as the countryside, as was the case for his series of trains covered in steam. Early in 1877 Monet took lodgings near the Gare Saint-Lazare where he determined to paint the trains spewing out thick smoke: "I'll get them to delay the train for Rouen for half an hour. The light will be better then.” Monet dressed up and approached the Director of the station to implement his idea, which ended with a series of paintings of trains fogging out the station. As quoted in Sue Roe, The Lives of the Impressionists (London: Vintage, 2007), p. 173.
} 


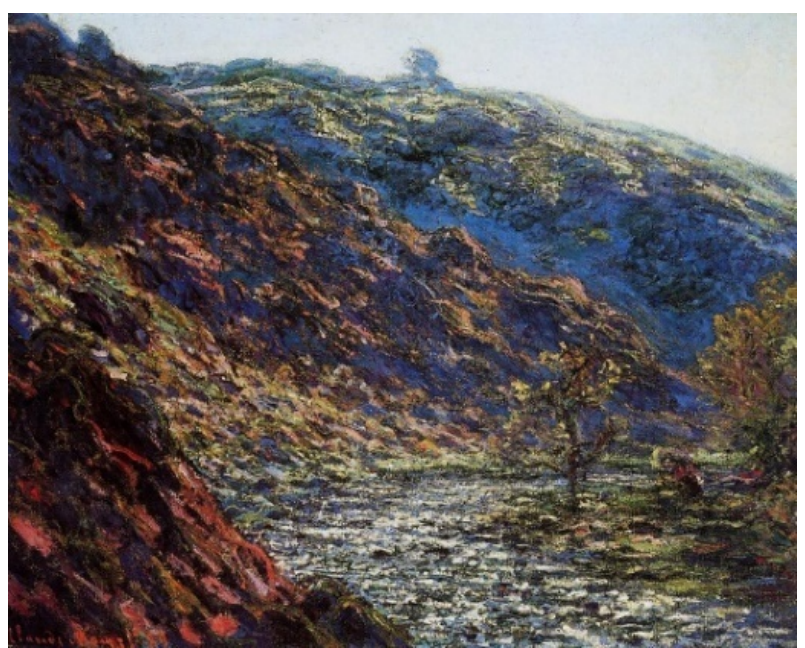

Figure 3. Claude Monet, The Old Tree Gorge of the Petite Creuse, 1889 (poulwebb).

However, there were aspects of nature that could not be adjusted and the constant aggravation mentioned by outdoors painters was the wind. When Vincent van Gogh began his legendary period at Arles, in the south of France, after the bright sun he noticed the winds, the mistral that blew him around on his excursions. He wrote to Theo from Arles on 9 March 1888 on the effect of the mistral:

Now at long last, this morning the weather has changed and has turned milder — and I've already had an opportunity to find out what this mistral's like too. I've been out on several hikes round about here, but that wind always made it impossible to do anything. The sky was a hard blue with a great bright sun that melted just about all the snow-but the wind was so cold and dry it gave you goose-pimples. (Vangoghletters.org. $583(06,27,2017)$ )

The mistral in the south of France was legendary as suggested by van Gogh's letter as he came to experience it while trying to paint out of doors. At Provence, it blew in its cold drafts from the northwest over 60 kilometers per hour and could last for several days, but often the disruption would be only one or two days. While an inconvenience for the painter, the winds did clean the atmosphere and produced, what painters described as the clear light of the south of France. The remainder of van Gogh's letter goes on to describe places where the painter might return for some interesting plein air work: "But even so I've seen lots of beautiful things—a ruined abbey on a hill planted with hollies, pines and grey olive trees." ${ }^{4}$ The down time of the mistral provided the painter a scouting opportunity so that his stay in the South would not be waisted.

How many paintings were lost because van Gogh could not work because of the wind? Fortunately, he was very productive so we do not lament not having enough van Gogh's, but clearly the mistral determined his output and the speed with which he had to work when being blown over the landscape. Monet commented on his problems with wind at Kervilahouen, Norway, September 1887:

Ten days after his arrival, Monet was expected to conclude his work at Kervilahouen quickly and move to "one or two varied places” on the coast. But difficulties began to mount up. First, it was winds so strong that canvas and sunshade had to be tied down, then the neap tides ...modified the appearance of his motifs. ... A brief respite in the weather coincided with a bout of severe fatigue. He therefore felt that he should continue with his "campaign"; his first estimate of ten days soon turned out to be very optimistic, and week after week went by. By working "in the same places in all weathers", Monet took a further step towards the "series" that he was later to paint, but it was a modest one, since only twelve paintings were under way altogether. (Wildenstein, 2016, p. 286)

\footnotetext{
${ }^{4}$ Vangoghletters.org. 583 (06, 27, 2017).
} 
The wind would be one difficulty, but painting outside in the winter brought new challenges. We have an account of this from Wildenstein where the Le Havre columnist Leon Billot came upon Monet: "We saw a foot warmer, then an easel, then a man huddled in three overcoats, wearing gloves, and with his face half-frozen: it was Monet studying snow effects” (Wildenstein, 2016, p. 87).

Surely, painting outside in winter would have speeded up the approach the painter would have to his subject. For those scenes in the bright light of good weather, the painter had another problem as to the light changed over the field of vision. At Saintes-Maries-sur-Mer in June 1888 Vincent wrote to his brother on the problem of changing light (see Figure 4):

I'm writing to you from Saintes-Maries on the Mediterranean at last—-the Mediterranean-has a colour like mackerel, in other words, changing—you don't always know if it's green or purple—you don't always know if it's blue-because a second later, its changing reflection has taken on a pink or grey hue. ${ }^{5}$

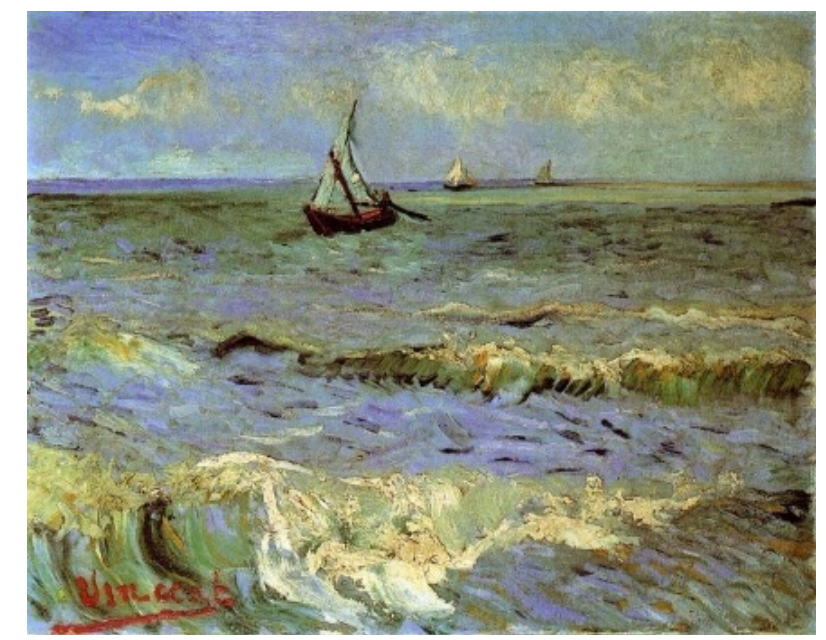

Figure 4. Vincent van Gogh, The Sea at les Saintes-Maries-de-la-Mer, 1888 (wikiart).

Van Gogh's observation about changing hue suggested the plein air artist would have to decide on one tone in this changing envelope of color and move on to the next effect. Monet's approach to changing light was countered by changing canvases for the same view during the hours of the day. There are records where he works on several canvases over a day to capture the effects of changing light. Parallel with the working in series was the reduction of landscape material to a single motif where tone and color might be the main subject of the painting. This was where Monet introduced the motif as seen in the cliffs at Etretat, the scene at the rivers Creuse, the London parliament buildings and the haystacks at Giverny. This allowed Monet to focus his light effects on a main subject and those considerations of landscape painting-perspective, space transitions, etc. would not be part of the image reading but the dazzle surface of light reflection became the point of the painting.

The dominated message with Monet's "motif series” was to focus on pure painting. Monet was as Camille Pissarro described him "not a landscape painter, but a great decorative painter” (Wildenstein, 2016, p. 515). If a picture did not have to meet all the requirements of landscape information, the artist could simplify and concentrate on color-light and brushwork. Monet selected situations where he could focus on one element in

\footnotetext{
${ }^{5}$ Vangoghletters.org. 619 (06, 27, 2017).
} 
landscape, often without figures or complicated aerial views. It would be in these exquisite tones and simplified composition that abstraction became seductive and painting found its raison d'etre in the arena of image making at the end of the century. Painting could be an aesthetic joy. Renoir had the last comment on this art of pure enjoyment: "To my mind, a picture should be something pleasant, cheerful, and pretty, yes pretty! There are too many unpleasant things in life as it is without creating still more of them." ${ }^{6}$ The painter was calling for hedonism in the great out of doors.

Beyond the encounters with weather, the plein air painter had to do a lot more planning than the studio painter. This might start with a notion to travel to a new region of the country as van Gogh did when he visited the sea at Sainte Maries or Monet travelling to the rivers Creuse and the fields of Giverny. Then there was the problem of supplies, van Gogh's letters are filled with requests to his brother to send paint and canvases (and money) and it must have been an ordeal for Monet to transport his numerous canvases to his painting prospect on the Thames where he did his Houses of Parliament series. This would have been especially irritating when the London fog rolled in forcing him to decamp back to France to work on the paintings in his studio.

Overseas travel would require budget planning, accommodation, family considerations and, as with Monet in Brittany, a porter. Indeed, some the accounts read like expeditions where the painter is off in a foreign land searching for that gem in the landscape. The consideration of travel with the anticipation of fresh visions became a part of the excitement of painting on location where delicious discoveries awaited. In his visit to the Mediterranean, Monet could hardly contain himself on the aesthetic overload. He wrote in a note to Alice Hoschede, "The palms will make me despair...So much blue in the sky and the sea-it is impossible!" (Heinrich, 2011, p. 64).

\section{Accidents}

While plein air subjects were often discovered, others were sought as possible subjects of visual interest. In 1868 Monet and Pierre-Auguste Renoir were working west of Paris, near Bougival at the Ile de Croissy where civilisation met nature at La Grenouillere, the "floating café." Monet wrote to fellow painter Frederic Bazille that he had done some unsatisfactory sketches for a large salon picture of the popular meeting place (Wildenstein, 2016, p. 97). We can only guess as to the criteria the painter used to dismiss La Grenouillere sketches, but Monet's work up to that point had shown a competency with recorded naturalism. Perhaps the images did not come off because they lacked vitality that can come from straight copying.

The onsite paintings that followed were works that were highly successful because the artist had worked the balance between observed structure and gestural suggestion. For the Grenouillere paintings, Monet and Renoir set up on the east side of the Seine and worked out the division of the scene in terms of the foreground water, the moored boats, the restaurant and the "camembert" island with figures (see Figure 5). Here ladies in elegant, long dresses and men in waist coats and top hats enjoy the sun filled day. But it is not the figures that challenge the artists but the foreground water that ripples with reflections that change with every flicker of the breeze. Monet, especially, treated this complication with a color-patch system of bold horizontal strokes of dark and white with a mid blue and yellow-orange (the foliage reflection). While these marks were, overall, observed and controlled they do show areas of dry-brush at the end of the stroke. It would be in these areas of casualness that gave vitality to outdoor painting. The water surface required sharper tonal distribution whereas

${ }^{6}$ Goodreads.com/Pierre-August Renoir-quotes (5/24/2017). 
the far shore was open to more mixing of the orange-green colors to suggest the foliage. Monet had learned that pictures in nature required both structure and gestural vitality or happy accidents to make the scene come off with a fresh vision.

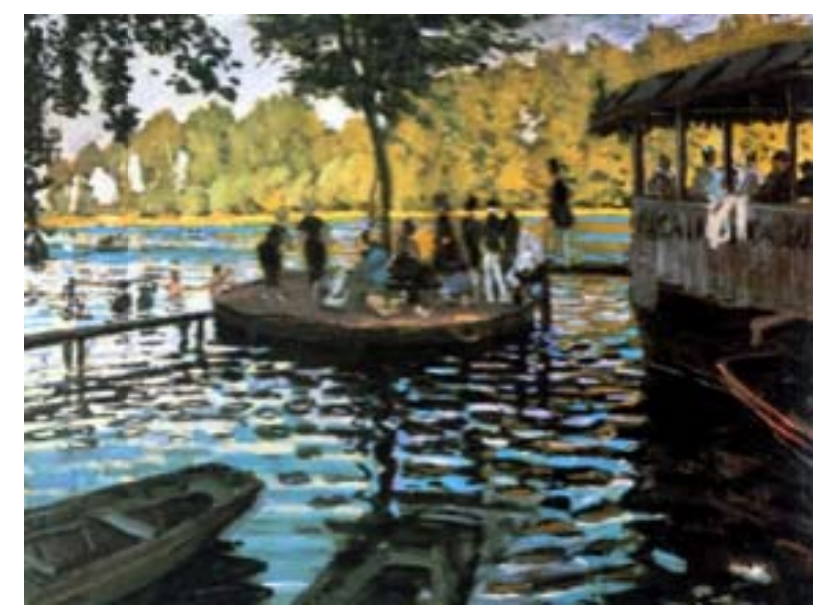

Figure 5. Claude Monet, La Grenouillere, 1869 (wikiart).

We find this approach to using gestural accidents particularly in the paintings of Berthe Morisot where she slashes at the canvas for foliage effects. In her painting from 1874 of Eugene Manet with his daughter, beyond the circle of the figures, the bushes and foreground grass become passages of abstract expressionism where the chance smearing of paint has moved away from naturalist recording to random effects. Her brushwork, while descriptive, was the result of accidents that assured visual interest and vitality in the subject (see Figure 6).

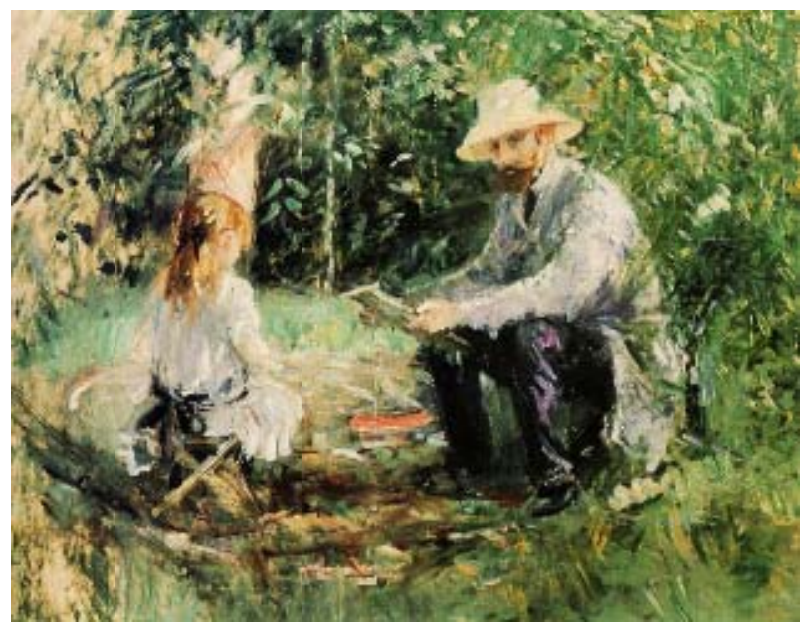

Figure 6. Berthe Morisot, Eugene Manet Painting with His Daughter in the Garden, 1874 (wikiart).

The Impressionist could have selected the easier subject but Monet made it clear this was not what he sought from nature. He wrote to critic Gustave Geffroy on 22 June 1890: "I have again begun on things that are impossibly to do: water with waterweeds undulating on the bottom...It is admirable to look at, but it is driving me mad trying to do it” (Wildenstein, 2016, p. 340). This was to be his last series where Monet settled on his "sweet village" at Giverny to make paintings of nature into his old age. This would be domestic plein air as the artists did not have to deal with the logistics of travel but could set up his subject as a gardener before painting 
at home. The waterlily pond held the greatest complexity for Monet because it had underwater plants as well as the reflected surface, which included sky and clouds (see Figure 7). This series involved a collection of instances that led to a final design. One part would capture an effect and subsequent marks would lead to design of overlapping brushwork. We know before the waterlilies were accepted for the Paris Orangerie, the artist worked on the canvases at his Giverny studio for years. By this time, they had become great abstractions where record, gesture and effect became intertwined in a most beautiful decoration. Pierre Georgel, who wrote the catalogue for the Orangerie waterlilies, commented on the future effect of the work as Monet's most “'expressionist' paintings and one can understand the impression they made on admirers of gestural abstraction when they were first shown to the public forty years later” (Georgel, 1999, p. 19).

Contemporary comments would tend to indicate that the Impressionists considered loose handling of paint as part of the out of doors experience. Of course, the most famous comment came from the critic Louis Leroy in Le Charivari who disparagingly commented on the first Impressionist work as unfinished-an impression (and thus the name adopted). Morisot would have received her share of the unfinished work criticism but there were contemporary critics who praised her "intuitiveness, spontaneity, and delicacy."7 In her painting, working quickly became valued as the shift to pure painting was growing with some critics and commentators. There had been gradual shift from using paint to record nature and to develop the medium to allow for inspiration and discovery - to express oneself as Morisot described it. If the goal of Impressionism was to record nature, as the naturalist had started, the painters had begun to push the envelope of just seeing. It had become obvious that invention and expression were part of the mix when an artist went before nature. By the fourth Impressionist Exhibition, the French critic Henry Havard wrote: "I confess humbly I do not see nature as they do, never having seen these skies fluffy with pink cotton, these opaque and moiré waters, this multi-colored foliage. Maybe they do exist. I do not know them.”8 The painter Paul Signac observed the change:

To think that these painters, because they have condemned themselves to working exclusively from nature, imagine that they are "naturalists". No, Monsieur Monet, you are not a naturalist...Bastien-Lepage is much closer to nature than you! Trees in nature are not blue, people are not violet... and your great merit is precisely to have painted them thus, as you felt them to be, out of your love of beautiful colours, and not as they are....

\footnotetext{
${ }^{7}$ National Museum of Women in the Arts, nmwa.org/Berthe Morisot. (5/23/2017)

8 Reproduced by Beth Gersh-Nesic in thoughtco.com/impressionism-art-history-183262.

${ }^{9}$ As quoted in Wildenstein, pp. 382-83.

The Impressionists exhibited in 1873 in photographer Nadar's studio on the boulevard des Capucines. Art critic Armande Silvestre wrote on the group's style as "based on a fine and exact observation of the relation of one tone to another." Sue Roe in her book The Lives of the Impressionists commented on the critic's statement: "Here he exaggerated, claimed that their methods were scientific, based upon a scale of tones. In reality the painters' method was largely intuitive, loosely based on the techniques Pissarro had taught Cezanne: to model forms by capturing the rhythms of light and air rather than being tied to 'accurate' drawing." See p. 124.
} 


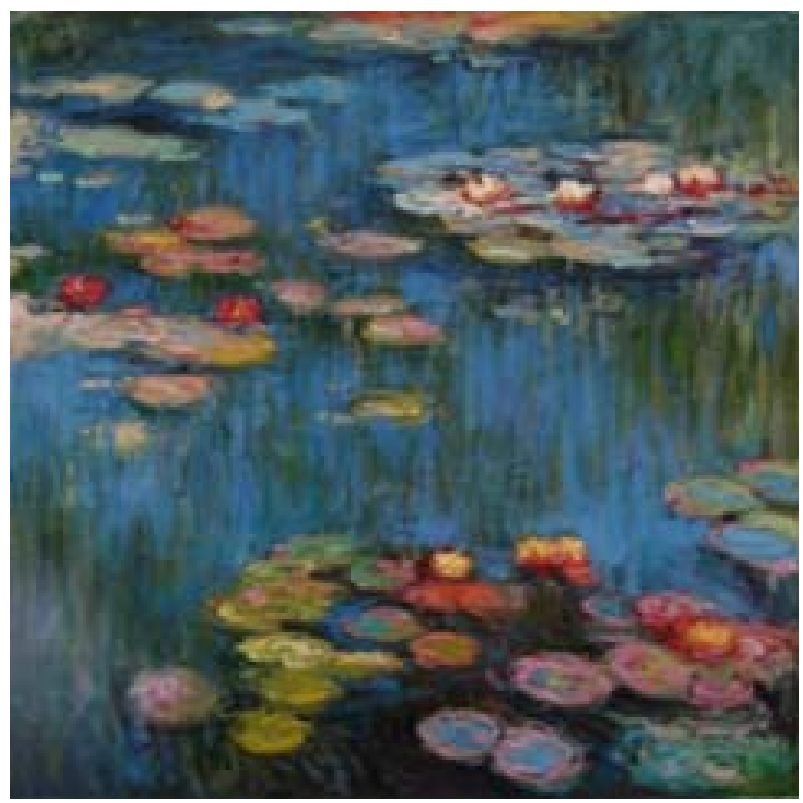

Figure 7. Claude Monet, Waterlilies, c. 1914-17 (wikiart).

\section{Conclusion}

By the eighth exhibition, 1886, the title of Post-Impressionist might have equally applied to the group as they followed their own subjective path. Claude Monet became the master of the motif with his water garden at Giverny and moved painting clearly into abstraction. Berthe Morisot had broken the ground into abstract expressionism—a term coined for later modern painters such as Wassily Kandinsky. Vincent van Gogh would become the father of modern expressionism firmly establishing the direction for 20th-century painting. The subjective had replaced the objective approach of the academy and we were on to modernism. The proven approaches to plein air painting began with a desire to record nature, but ended up with new approaches that changed what would be valued in art.

\section{References}

Georgel, P. (1999). Claude Monet: waterlilies. Hazan: Tours.

Gersh-Nesic, B. (2017). thoughtco.com/impressionism-art-history-183262-thoughtco.com/eugeneboudin-quickfacts-183339. $(05 / 07 / 2017)$

Goodreads.com/Pierre-August Renoir-quotes. (05/24/2017)

Heinrich, C. (2011). Claude Monet 1840-1926. Taschen: Basic Art 2.0

National Museum of Women in the Arts.nmwa.org/Berthe Morisot. (05/23/2017)

Roe, S. (2007). The lives of the impressionists. London: Vintage.

Ruskin, A. (1973). Nineteenth century art. New York: McGraw-Hill.

Shikes, R. E., \& Harper, P. (1980). Pissarro: His life and work. New York: Horizon Press.

Vangoghletters.org.583, 619. (06, 27, 2017)

Wildenstein. D. (2016). Monet: The triumph of impressionism. Koln: Taschen. 